\title{
Relationships among goodness-of-example, category norms, and word frequency
}

\author{
CAROLYN B. MERVIS and JACK CATLIN \\ Cornell University, Ithaca, New York 14853 \\ and \\ ELEANOR ROSCH \\ University of California, Berkeley, California 94720
}

\begin{abstract}
The relationship between two indices of the internal structure of natural-language categories, goodness-of-example (as measured by subjects' ratings), and item dominance (as assessed by category-norm data) was assessed by correlational analysis. For all eight categories examined, the two variables are significantly positively correlated. Item dominance also bears some positive relationship to word frequency, while goodness-of-example does not.
\end{abstract}

Natural-language categories have internal structure, in that not all members of a given category have equal status within that category. One symptom of this internal structure is goodness-of-example ratings; when subjects are asked to rate various members of a category on the basis of how well each item represents their idea of the meaning of the category name, the subjects concur in rating some items as being better examples of the category than are others (Rosch, 1973, 1975). A second symptom of the internal structure of categories is item dominance in category norms; when subjects are asked to list instances of a category, given only the category name as stimulus, some items are listed with much greater frequency across subjects than are others (Cohen, Bousfield, \& Whitmarsh, 1957; Battig \& Montague, 1969).

The speed with which subjects are able to judge that a particular item is in fact a member of a given category is influenced in similar ways by goodness-ofexample (Rips, Shoben, \& Smith, 1973; Rosch, 1973) and by item dominance (Wilkins, 1971; Loftus, 1973). It thus seems plausible that the two variables, goodness-ofexample and item dominance, may be closely related measures of the same underlying factor; in confirmation of this, Rips et al. found evidence that the two variables are highly correlated for the category bird.

Subsequent studies (e.g., Smith, Shoben, \& Rips, 1974; Glass, Holyoak, \& O'Dell, 1974) have tended to assume that the correspondence between goodness-ofexample and item dominance is a general one, holding across a variety of natural-language categories. In the

This research was conducted while Carolyn Mervis was a National Science Foundation predoctoral fellow, and was supported by a grant from the Cornell Research Grants Committee to Jack Catlin. Requests for reprints should be sent to Carolyn Mervis, Department of Psychology, Uris Hall, Cornell University, Ithaca, New York 14853. present study, we use correlational analysis to show that there is in fact a systematic correspondence between goodness-of-example and item dominance for a variety of categories. In addition, we examine the relationship between each of these variables and word frequency.

\section{METHOD}

The item-dominance data used in the correlational analysis were the data for eight categories from the Battig and Montague category norms: bird, carpenter's tool, fruit, furniture, sport, vegetable, vehicle, and weapon. Word frequency was determined for each item in the data by reference to the Kučera and Francis (1967) tabulation, adding together singular, plural, and possessive forms. The norms used for goodness-of-example, for between 50 and 60 of the Battig and Montague instances for each of the eight categories (including all instances for each category which occurred 10 or more times), were those constructed by Rosch (1975). Spearman rank-order correlations between item dominance and goodnessof-example, between item dominance and word frequency, and between word frequency and goodness-of-example were calculated for each category, using the Statistical Package for the Social Sciences NONPAR CORR program (Nie, Bent, \& Hull, 1970).

\section{RESULTS AND DISCUSSION}

The correlations computed between item dominance and goodness-of-example, between item dominance and word frequency, and between word frequency and goodness-of example are presented in Table 1. Type I error was controlled at the .05 level (two-tailed) per column of correlations using the adjusted-significancelevels method. All of the correlations between item dominance and goodness-of example were significant. Two of the eight correlations between item dominance and word frequency were significant; all eight were positive. None of the correlations between word frequency and goodness-of-example were significant.

There is clearly a definite relationship between item dominance and goodness-of example, confirming the 
Table 1

Correlations Among Various Measures

\begin{tabular}{|c|c|c|c|}
\hline \multirow[b]{2}{*}{ Category† } & \multicolumn{3}{|c|}{ Correlations } \\
\hline & $\begin{array}{c}\text { Item Dominance } \\
\text { With } \\
\text { Goodness-of-Example }\end{array}$ & $\begin{array}{l}\text { Item Dominance } \\
\text { With } \\
\text { Word Frequency }\end{array}$ & $\begin{array}{l}\text { Word Frequency } \\
\text { With } \\
\text { Goodness-of-Example }\end{array}$ \\
\hline Bird (54) & $.69 *$ & .34 & .00 \\
\hline Carpenter's Tool (60) & $.74 *$ & .22 & .12 \\
\hline Fruit (51) & $.70^{*}$ & $.42 *$ & .18 \\
\hline Furniture (59) & $.54^{*}$ & .22 & -.27 \\
\hline Sport (59) & $.55^{*}$ & .22 & .01 \\
\hline Vegetable (56) & $.74^{*}$ & .38 & -.07 \\
\hline Vehicle $(50)$ & $.57 *$ & $.46^{*}$ & .26 \\
\hline Weapon (60) & $.48 *$ & .20 & -.27 \\
\hline
\end{tabular}

$\Varangle$ Numbers in parentheses indicate the number of instances for each category.

*Adjusted $p<.05$.

earlier results obtained by Rips et al. Thus, this correspondence appears to be a general one across natural-language categories. In addition, as item dominance also shows some relationship to word frequency, while goodness-of-example does not, goodness-of-example may be a more direct measure of the common factor underlying the two variables of interest.

\section{REFERENCES}

Battig, W. F., \& Montague, W. E. Category norms for verbal items in 56 categories: A replication and extension of the Connecticut category norms. Journal of Experimental Psychology Monograph, 1969, 80(3, Part 2).

Cohen, B. H., Bousfield, W. A., \& Whitmarsh, G. A. Cultural norms for verbal items in 43 categories. ONR Technical Report No. 22. Storrs, Conn: University of Connecticut, 1957.

KuČera, H., \& Francis, W. N. Computational analysis of present-day English. Providence, R.I: Brown University Press, 1967.

Glass, A. L.. Holyoak, K. J., \& O’Dell, C. Production frequency and the veritication of quantified sentences. Journal of Verbal Learning and Verbal Behavior, 1974, 13. 237-254.
Loftus, E. F. Category dominance. instance dominance, and categorization time. Journal of Experimental Psychology. 1973, 97, 70-74.

NiE, N. H., Bent, D. H., \& Hull, C. H. Statistical package for the social sciences. New York: McGraw-Hill, 1970.

Rips, L. J., Shoben, E. J., \& Smith, E. E. Semantic distance and the verification of semantic relations. Journal of Verbal Learning and Verbal Behavior, 1973, 12, 1-20.

Rosch. E. On the internal structure of perceptual and semantic categories. In T. E. Moore (Ed.), Cognitive development and the acquisition of language. New York: Academic Press. 1973.

Rosch, E. Cognitive representations of semantic categories. Journal of Experimental Psychology: General, 1975, 104. 192-233.

Smith, E. E., Shobein, E. J., \& Rips, L. J. Structure and process in semantic memory: A featural model for semantic decisions. Psychological Review, 1974, 81, 214-241.

Thorndike, E. L., \& LORGE, I. The teacher's word book of 30.000 words. New York: Bureau of Publications. Teachers College, Columbia University. 1944.

Wilkins, A. J. Conjoint frequency, category size, and categorization time. Journal of Verbal Learning and Verbal Behavior, 1971, 10, 382-385.

(Received for publication November 17, 1975.) 